\title{
IS PRENATAL YOGA EFFECTIVE IN REDUCING ANXIETY AND DEPRESSION DURING PREGNANCY? A NEW EVIDENCE FROM KUDUS, CENTRAL JAVA
}

\author{
Ika Yulianti',2), Supriyadi Hari Respati3), Aris Sudiyanto4) \\ 1)Masters Program in Public Health, Universitas Sebelas Maret \\ 2)Diploma Program in Midwifery, Universitas Borneo Tarakan \\ 3)Department of Obstetrics and Gynecology, Dr. Moewardi Hospital, Surakarta \\ 4)Department of Psychiatry, Dr. Moewardi Hospital, Surakarta
}

\begin{abstract}
Background: Studies have shown that up to 33 percent of women experience clinical depression or an anxiety disorder at some point during pregnancy. Anxiety and depression in pregnancy can lead to low fetal quality, increased risk of pregnancy complication and developmental disorder of the child. Antidepressant treatment may cause recurrence or addiction rate of up to 50\%. In theory, yoga can relieve undesirable psychic symptoms such as anxiety and depression during pregnancy. This study aimed to determine the effect of prenatal yoga on anxiety and depression during pregnancy.

Subjects and Method: This was a randomized controlled trial conducted at Budi Luhur clinic in Kudus, Central Java, from 27 December 2017 to 7 February 2018. A total of 102 pregnant women was allocated at random into the intervention group $\left(n_{1}=51\right)$ and control group $\left(n_{2}=51\right)$. The independent variable was prenatal yoga. The dependent variables were anxiety and depression. The data were collected by questionnaire. Difference in the dependent variables between the two groups was tested by Mann-Whitney test and multiple linear regression.

Results: The mean level of anxiety was lower in the intervention group than the control group both at two weeks after the intervention $(b=-9.25 ; 95 \% \mathrm{CI}=-10.22$ to -8.28; $\mathrm{p}<0.001)$ and four weeks after the intervention $(\mathrm{b}=-5.79 ; 95 \% \mathrm{CI}=-$ 7.68 to $-3.90 ; \mathrm{p}<0.001)$. The mean level of depression was lower in the intervention group than the control group both at two weeks after the intervention $(\mathrm{b}=-10.82 ; 95 \% \mathrm{CI}=-12.29$ to $-9.35 ; \mathrm{p}<0.001)$ and four weeks after the intervention $(b=-2.58 ; 95 \% \mathrm{CI}=-3.98$ to $-1.18 ; \mathrm{p}<0.001)$.
\end{abstract}

Conclusion: Prenatal yoga intervention is effective in reducing anxiety and depression during pregnancy.

Keywords: prenatal yoga, anxiety, depression

\section{Correspondence:}

Ika Yulianti. Masters Program in Public Health,UniversitasSebelasMaret, Jl. Ir. Sutami 36 A, Surakarta 57126, Central Java.Email:ikatamaevan@gmail.com. Mobile: +628115440036 . 